\title{
Trials to overcome drug resistance to EGFR and ALK targeted therapies - past, present, and future
}

\author{
Johanna N. Spaans ${ }^{1}$ and Glenwood D. Goss ${ }^{1,2,3 *}$ \\ 1 Ottawa Hospital Research Institute, Ottawa, ON, Canada \\ 2 Ottawa Hospital Cancer Centre, Ottawa, ON, Canada \\ ${ }^{3}$ Department of Medicine, University of Ottawa, Ottawa, ON, Canada
}

Edited by:

Vera Hirsh, McGill University Health

Centre, Canada

\section{Reviewed by:}

Meng Xu Welliver, The Ohio State

University James Cancer Center, USA

Nathalie Heuzé-Vourc'h, CEPR

INSERM U1100/EA6305, France

\section{${ }^{*}$ Correspondence:}

Glenwood D. Goss, 501 Smyth Road, Ottawa, ON K1H 8L6, Canada

e-mail:ggoss@toh.on.ca
Molecularly targeted agents are changing the therapeutic landscape in advanced non-small cell lung cancer. Since the discovery of sensitizing mutations in the epidermal growth factor receptor (EGFR) and anaplastic lymphoma kinase (ALK) domain, clinical investigations have focused on optimizing the efficacy of EGFR and ALK tyrosine kinase inhibitors by addressing therapeutic resistance that commonly develops within a year of treatment initiation. Here, we review the clinical trials of novel therapies and combination regimens that have been undertaken in response to our evolving understanding of the mechanisms of resistance to targeted therapy. The aim of these trials was to enhance the therapeutic efficacy of targeted therapies by improving blockade and/or inhibiting parallel or compensatory signaling pathways. We have documented the sequential conduct of EGFR and ALK biomarker-driven trials in order to highlight particular pitfalls and successes, which should be considered in the design of future trials. Although there remain significant challenges, substantial gains have been made in our understanding of cellular resistance. This knowledge will drive the design of future trials to the benefit of lung cancer patients.

Keywords: EGFR, ALK, resistance, molecular therapy, clinical trial
Lung cancer is the leading cause of cancer related deaths worldwide (1). Non-small cell lung cancer (NSCLC) represents approximately $85 \%$ of all lung cancers (2). In the advanced disease setting, systemic platinum-based chemotherapy yields survival rates of approximately 1 year (3). In the last decade, the targeted inhibition of oncogenic driver mutations with molecular therapies of which the epidermal growth factor receptor (EGFR) and the anaplastic lymphoma kinase (ALK) are the most studied targets, has seen dramatic improvements in overall survival in defined subsets of patients $(4,5)$. However, despite impressive early response rates, most patients progress within a year (4). Herein, we review clinical trials undertaken in response to our evolving understanding of the oncogenic drivers and molecular mechanisms of drug resistance.

\section{BACKGROUND}

Given its important role in tumor growth and proliferation, the EGFR pathway has been the focus of intense clinical investigation across many tumor sites $(6,7)$. The high protein expression levels observed in NSCLC across all histologies (8), particularly among those with advanced disease (9), provided the initial impetus for the early lung cancer trials targeting the EGFR pathway by small molecule tyrosine kinase inhibitors (EGFR-TKIs) and anti-EGFR monoclonal antibodies.

Early trials in advanced NSCLC evaluated EGFR-TKIs as both monotherapy after chemotherapy failure and in combination with chemotherapy in the first-line setting. As a monotherapy, the EGFR-TKI erlotinib, was shown to improve progression free survival (PFS) (2.2 vs. 1.8 months, $p<0.001$ ) and overall survival (OS) over best supportive care (6.7 vs. $4.7, p<0.001)$ in unselected NSCLC patients with advanced disease who had failed one or two prior lines of chemotherapy (BR 21) (10). Although gefitinib, another EGFR-TKI, was similarly able to delay disease progression over placebo in the second/third-line setting (3.0 vs. 2.6 months, $p=0.0006$ ), the lack of overall survival benefit (5.6 vs. 5.1 months, $p=0.087$ ) in the definitive phase III trial (ISEL) (11)resulted in the withdrawal of gefitinib's accelerated FDA approval, which was based on encouraging phase II data (IDEAL-1, IDEAL-2) $(12,13)$. Disappointingly, when used in combination with upfront chemotherapy in unselected patients with advanced NSCLC, neither erlotinib nor gefitinib was shown to improve overall survival (14-17). The strategy of combining EGFR-TKIs and chemotherapy, therefore, has since largely been abandoned.

Objective responses in most of the early EGFR-TKI trials in unselected patients was quite variable, with many trials independently identifying a small subgroup of extreme responders (10, 11), against a large background of patients with primary resistance to EGFR inhibition. In these trials, the extreme responders were most commonly defined by their clinical and ethnic characteristics (Asian, non-smokers) and not by their pre-treatment EGFR protein expression levels. With the discovery of the activating EGFR mutations in exon 19 and 21 of the kinase domain $(18,19)$, came a number of retrospective mutational studies of the earlier anti-EGFR trials, which confirmed the importance of these mutations $(20,21)$. These studies lead to the molecular characterization of EGFR-TKI responders and the subsequent EGFR mutation-positive biomarker-driven trials, detailed below. 


\section{PAST CLINICAL TRIALS ADDRESSING RESISTANCE}

The restriction of EGFR-TKI trials to patients whose tumors harbored activating EGFR mutations represented the first attempt to address primary drug resistance, by limiting exposure in patients unlikely to benefit from EGFR-TKIs. Six large randomized phase III trials that enriched or selectively enrolled patients with activating EGFR mutations definitively confirmed the benefit of firstgeneration reversible EGFR-TKIs over standard chemotherapy in the first-line setting (Table 1) (22-27). These trials, which collectively enrolled over 2200 patients, showed a doubling of response rate to $60-80 \%$ over chemotherapy alone in patients whose tumors harbored the EGFR mutation (22-27). In the four trials that only enrolled EGFR-mutant positive NSCLC patients (two gefitinib, two erlonitib), EGFR-TKIs were shown to extend PFS by 3-8 months (24-27). Consequently, targeted monotherapy with erlotinib or gefitinib has now become standard of care in the first-line setting in patients with EGFR mutation-positive tumors.

Due to their different mechanism of action, anti-EGFR monoclonal antibodies have also been evaluated in the management of advanced NSCLC. The most well studied of these agents is cetuximab, a monoclonal chimeric IgG1 antibody, that inhibits EGFR pathway activation by binding to the EGF receptor (28). Unlike its small molecule counterpart, monotherapy trials of cetuximab were disappointing in advanced NSCLC (29). However, cetuximab has been successfully combined with chemotherapy in the firstline setting. In a large phase III trial that enrolled 1125 patients with advanced NSCLC (FLEX) (30), cetuximab was shown to improve overall survival (11.3 vs. 10.1 months, $p=0.004$ ) when combined with cisplatin and vinorelbine, with greater efficacy noted in patients with higher EGFR protein expression (31). While a similar smaller study $(n=676)$ of cetuximab with a carboplatin/paclitaxel regimen (BMS099) (32) did not demonstrate improved PFS or OS with the addition of cetuximab, a metaanalysis of four randomized phase II\&III trials (which included the BMS099 study results) did show that cetuximab with first-line

Table 1 | Randomized phase III trials of first-generation EGFR-TKIs in EGFR mutation (+)/enriched populations.

\begin{tabular}{|c|c|c|c|c|}
\hline Study & Agent & $\mathrm{EGFR}+/ \mathrm{N}$ & $\begin{array}{l}\text { PFS (EGFR+) } \\
\text { (months) }\end{array}$ & $\begin{array}{l}\text { OS (EGFR+) } \\
\text { (months) }\end{array}$ \\
\hline NEJ002 (24) & Gefitinib & $224 / 224$ & $\begin{array}{l}10.8 \text { vs. } 5.4 \\
\text { (HR 0.3) }\end{array}$ & $\begin{array}{l}27.7 \text { vs. } 26.6 \\
\text { (HR 0.89) }\end{array}$ \\
\hline $\begin{array}{l}\text { WJTOG-3405 } \\
\text { (25) }\end{array}$ & Gefitinib & $192 / 192$ & $\begin{array}{l}9.2 \text { vs. } 6.3 \\
\text { (HR } 0.5)\end{array}$ & $\begin{array}{l}36 \text { vs. } 39 \\
(H R \text { 1.19) }\end{array}$ \\
\hline $\begin{array}{l}\text { OPTIMAL } \\
(26)\end{array}$ & Erlotinib & $154 / 154$ & $\begin{array}{l}13.1 \text { vs. } 4.6 \\
\text { HR } 0.16\end{array}$ & HR 1.065 \\
\hline EURTAC (27) & Erlotinib & $153 / 153$ & $\begin{array}{l}9.7 \text { vs. } 5.2 \\
\text { HR } 0.37\end{array}$ & $\begin{array}{l}19.3 \text { vs. } 19.5 \\
\text { HR } 1.04\end{array}$ \\
\hline IPASS (22) & Gefitinib & $261 / 1217$ & $\begin{array}{l}9.5 \text { vs. } 6.3 \\
\text { HR } 0.48\end{array}$ & $\begin{array}{l}21.6 \text { vs. } 21.9 \\
\text { HR } 1.0\end{array}$ \\
\hline SIGNAL (23) & Gefitinib & $42 / 309$ & $\begin{array}{l}8.0 \text { vs. } 6.3 \\
\text { HR } 0.54\end{array}$ & $\begin{array}{l}27.2 \text { vs. } 25.6 \\
\text { HR } 1.04\end{array}$ \\
\hline
\end{tabular}

platinum-based chemotherapy improved both PFS and OS (33). Cetuximab's inconsistent and limited clinical efficacy, however, has restricted the uptake and regulatory approval of this antiEGFR monoclonal antibody in advanced NSCLC. While other anti-EGFR monoclonal IgG1 antibodies, such as matuzumab, have demonstrated some efficacy in combination with chemotherapy in the second-line setting in phase II trials (34), other anti-EGFR monoclonal IgG2 antibodies (e.g., panitumumab) in combination with chemotherapy have shown little activity, even in patients with EGFR-mutant disease (35). Newer fully human recombinant antiEGFR IgG1 monoclonal antibodies (e.g., necitumumab), which lack the immunoreactivity of earlier chimeric (human/mouse) monoclonal antibodies, are currently under investigation in certain histological subgroups in combination with chemotherapy, as detailed below.

As noted previously, even in the presence of sensitizing EGFR mutations, only $60-80 \%$ of patients with advanced NSCLC respond to EGFR-TKIs. Despite earlier failed attempts to combine EGFR-TKIs with chemotherapy, other combination regimens were evaluated early in the clinical development of EGFR-TKIs, in an attempt to expand and enhance their therapeutic efficacy. To understand the rationale for these, and other combination regimens evaluated in molecular oncology clinical trials, it is useful to consider the therapeutic strategies advanced by Dancey and colleagues (36) to address targeted therapy drug resistance, namely to (1) augment the first agent's activity; (2) enhance single target blockade; (3) inhibit multiple targets or multiple pathways; and (4) inhibit compensatory pathways. While combination therapies with chemotherapy used the first of these strategies, strategies two to four have guided most clinical research in the acquired resistance setting, as detailed below.

\section{PAST TRIALS OF COMBINATION THERAPIES}

Dual targeting of a single receptor was the rationale behind the early trials of combined EGFR-TKI and anti-EGFR monoclonal antibody therapies, which, due to the off-target effects of the firstgeneration EGFR-TKIs, proved very toxic (37). Multiple pathway inhibition was the guiding strategy behind combining EGFRTKIs with the anti-VEGF monoclonal antibody, bevacizumab, given its earlier success in improving overall survival in advanced NSCLC when given with chemotherapy (38). Although early trials of dual VEGF and EGFR inhibition were encouraging (39, 40), more recent trials in unselected populations of VEGF/EGFR inhibitors, such as vandetanib, do not support this approach in the management of advanced NSCLC (41).

\section{CURRENT CLINICAL TRIALS ADDRESSING RESISTANCE}

Despite dramatic responses in patients whose tumors harbor EGFR activating mutations, most patients become resistant to EGFR-TKIs within the first year $(10,11)$. The majority of current trials are, therefore, focused on addressing the mechanisms of acquired resistance (Table 2). The most common of these mechanisms is the development of a second mutation of the EGFR, namely the T790M mutation (T790M), which occurs in up to $60 \%$ of those with EGFR-TKI resistant disease (42). The newer secondgeneration pan-HER irreversible inhibitors provide compensatory pathway inhibition by direct targeting of the resistant T790M 
Table 2 | Select trials addressing acquired resistance to targeted therapy

\begin{tabular}{|c|c|c|c|}
\hline Line of therapy & Agents & Trial & PFS (months) \\
\hline \multicolumn{4}{|c|}{ MONOTHERAPY TRIALS TARGETING THE EGFR DOMAIN } \\
\hline First line & Afatinib vs. pem/cispl & LuxLung 3 (45) & 11.1 vs. $6.9(p=0.001)$ \\
\hline First line & Afatinib vs. gem/cispl & LuxLung 6 (46) & 11.0 vs. $5.6(p<0.0001)$ \\
\hline First line & Dacomitinib vs. gefitinib & ARCHER 1050 & Results pending \\
\hline Second line & Afatinib vs. placebo & LuxLung 1 (43) & 3.3 vs. $1.1(p<0.0001)$ \\
\hline Second line & Dacomitinib vs. placebo & BR $26(44)$ & 2.7 vs. $1.4(p<0.0001)$ \\
\hline \multicolumn{4}{|c|}{ COMBINATION THERAPIES TARGETING THE MET COMPENSATORY PATHWAY } \\
\hline Second/third line & Tivantinib + erlotinib vs. erlotinib + placebo & Marquee $^{a}(47)$ & 3.6 vs. $1.9(p<0.0001)$ \\
\hline Second/third line & Onartuzumab + erlotinib vs. erlotinib + placebo & METLunga (48) & 2.7 vs. $2.6(p=0.92)$ \\
\hline
\end{tabular}

aTrial stopped early for futility to meet primary endpoint.

mutation and bind irreversibly to 2 or more receptors of the EGFR domain, thus providing enhanced EGFR pathway blockade. Of the second-generation inhibitors, afatinib and dacomitinib have been the most extensively studied, in both heavily pre-treated patients and in the first-line setting. Afatinib has been evaluated in an EGFR-mutant enriched population who had failed one to two lines of chemotherapy and an EGFR-TKI (LUX-Lung 1) (43). In this placebo-controlled phase III trial, afatinib was shown to improve PFS (3.3 vs. 1.1 months, $p<0.0001$ ) but not overall survival (10.8 vs. 12.0 months, $p=0.87)(43)$. A similar study was also undertaken with dacomitinib (BR. 26) (44) in patients who had failed one to three lines of chemotherapy and an EGFR-TKI. As with afatinib, dacomitinib showed improved PFS ( 2.7 vs. 1.4 months, $p<0.0001$ ) but did not improve OS (6.8 vs. 6.3 months, $p=0.099$ ) (44).

Unlike the disappointing results observed in the second/thirdline setting, second-generation EGFR inhibitors have proven effective in the first-line setting in patients whose tumors harbor EGFR activating mutations. Specifically, afatinib has been shown to improve PFS compared to pemetrexed/cisplatin (LUX-Lung 3) (11.1 vs. 6.9 months, $p=0.001$ ) (45) and, more recently, compared to gemcitabine/cisplatin (LUX-Lung 6) (11.0 vs. 5.6 months, $p<0.0001$ ) (46). Dacomitinib is also being evaluated in a headto-head phase III trial against gefitinib (ARCHER 1050), with the results expected next year (www.clinicaltrials.gov: NCT01774721).

In the context of acquired resistance to anti-EGFR therapies, the activation of alternate signaling pathways by both adaptive mutations that develop outside the EGFR kinase domain and mutationindependent factors have also been described (49), and are informing novel combination therapies to address these acquired mechanisms of resistance. The most common of these alterations is MET activation, which occurs in up to $20 \%$ of patients with acquired resistance (50). Both small molecule inhibitors targeting MET and anti-MET monoclonal antibodies have been combined with first-generation EGFR-TKIs. The small molecule, tivantinib, and the monoclonal antibody onartuzumab have both been evaluated in the second-line setting in EGFR-TKI naïve patients after chemotherapy failure. In phase II trials, patients were screened and stratified by EGFR mutation status with planned subgroup analysis by both EGFR mutation and pre-treatment tumor MET expression levels. Despite promising phase II data in patients whose tumors were strongly positive for MET by immunohistochemistry (IHC) (51), the combination of onartuzumab and erlotinib in the phase III trial was not shown to improve PFS (2.7 vs. 2.6 months, $p=0.92$ ) or objective response rate (ORR) ( 8.4 vs. $9.6 \%, p=0.63$ ) and was stopped early for futility to meet its primary endpoint of improved OS (48). The small molecule tivantinib had a similar outcome, with the phase III trial discontinued prematurely for futility for the primary outcome of improved overall survival, which at the planned interim analysis was comparable to EGFR monotherapy ( 8.5 vs. $7.8, \mathrm{HR}=0.98, p=0.81$ ) (47). Given the failure of these phase III trials to improve survival, direct targeting of MET as a strategy to enhance EGFR-TKI efficacy has an uncertain future.

The failure of dual MET/EGFR inhibition to improve OS in the second-line setting can, in part, be attributed to fact that none of these trials, which were designed to address acquired resistance to EGFR-TKIs, restricted enrollment to patients with tumors harboring EGFR activating mutations and due to the lack of a robust biomarker predictive of efficacy to MET inhibition. The more focused strategy applied in the first-line setting to evaluate of the first and second-generation EGFR-TKIs, and more recently to ALK inhibitors, which limited enrollment to EGFR mutationpositive and ALK mutation-positive NSCLC, respectively, have been far more successful. In the case of the ALK inhibitor, crizotinib, accelerated approval was granted based on clinical activity observed in a phase I dose-escalation and expansion study, which screened over 1500 pre-treated patients and selectively enrolled 82 patients whose tumors screened positive for the ALK rearrangement (5\% prevalence) (52). Results of the definitive phase III trial of first-line crizotinib compared to chemotherapy have recently confirmed these initial findings (53). Using a similar approach of selective enrollment, the second-generation ALK inhibitor ceretinib (LDK378) has also recently achieved regulatory FDA drug approval in patients who have failed the crizotinib, by demonstrating antitumor activity and ORR of $\sim 60 \%$ in a heavily pre-treated populations in a phase I trial (ASCEND-1) (54).

THE FUTURE OF CLINICAL TRIALS OF ACQUIRED RESISTANCE Moving forward, clinical trials of acquired resistance will continue to focus on the testing of novel monotherapies and combination therapies targeting the EGFR kinase domain. In the former 
case, phase III clinical trials are currently on-going comparing the efficacy of the second-generation irreversible EGFR-TKIs against the first-generation inhibitors, in the second-line setting in advanced squamous NSCLC (LuxLung 8, afatinib vs. erlotinib, www.clinicaltrials.gov: NCT01523587) and in the first-line treatment of patients with EGFR-mutant disease (ARCHER 1050, dacomitinib vs. gefitinib, www.clinicaltrials.gov: NCT01774721). Disappointingly, the results of another phase III trial comparing first and second-generation EGFR-TKIs in the second/third-line setting (ARCHER 1009: dacomitinib vs. erlotinib) do not support the greater clinical efficacy of the newer EGFR-TKIs in unselected patients with advanced NSCLC (55). However, the results from the two on-going phase III trials, mentioned above, are eagerly awaited.

\section{THIRD-GENERATION EGFR-TKIS AND NEWER RECOMBINANT ANTI-EGFR MONOCLONAL ANTIBODIES}

A number of third-generation EGFR-TKIs are also in development, with AZ9291 and CO-1686 being the most advanced of these T790M-specific small molecule inhibitors. Results of early phase I trials of both AZ9291 and CO-1686 in EGFR mutationpositive NSCLC patients previously treated with EGFR-TKIs are encouraging. In both trials, which required screening biopsies for centralized T790M mutation testing, objectives responses of $\sim 60 \%$ in patients testing T790M positive at screening have been observed $(56,57)$, with responses also noted in patients lacking the T790M mutation receiving AZ9291, albeit less frequently (23\%) (56). Definitive phase III trials of these molecularly targeted agents are planned.

The recent success of the newer recombinant anti-EGFR monoclonal antibody, necitumumab, in combination with gemcitabinecisplatin chemotherapy over chemotherapy alone in the first-line treatment of patients with advanced squamous NSCLC (58) (OS: 11.5 vs. $9.9, p=0.012$ ) is also of interest in advanced NSCLC. Although potentially effective in the primary resistance setting, what role necitumumab will play in the acquired resistance setting in patients with squamous and non-squamous NSCLC histology remains to be determined.

\section{DUAL TARGETING OF THE EGFR KINASE DOMAIN}

Dual targeting of the EGFR kinase domain, although historically quite toxic, will also likely continue to be explored as a strategy to optimize EGFR-TKI therapy given the phase I dose-escalation and expansion trial demonstrating ORR of $\sim 30 \%$ with dual therapy with the anti-EGFR monoclonal antibody cetuximab and afatinib in patients with acquired resistance to first-generation EGFR-TKIs (59). These encouraging results, however, are tempered by the continued toxicity of this combination regimen with 77 and $69 \%$ of patients experiencing rash and diarrhea (any grade), respectively (59).

\section{SECOND-GENERATION ALK INHIBITORS}

As secondary mutations in the ALK domain have been identified in approximately one third of patients with acquired resistance to the ALK inhibitor crizotinib (60), clinical trials in the ALK resistance setting are also focused on the evaluation of more potent secondgeneration molecular therapies. Of note, high response rates with the newer second-generation ALK inhibitor, ceretinib, have been observed in patients with and without secondary ALK mutations (54), suggesting that their benefit in ALK-resistant disease may not be limited to patients with secondary ALK mutations. A number of other second-generation ALK inhibitors are also in early clinical development (e.g., AP26113), with promising phase I/II results emerging (61).

\section{DUAL EGFR AND MET INHIBITION}

While the dual inhibition of EGFR and MET-mediated pathway inhibition by direct MET targeting has not been successful to date, other c-MET inhibitors are being investigated (e.g., INC 280, $\mathrm{XL184)}$. A related mechanism of EGFT-TKI resistance is MET activation by its ligand hepatocyte growth factor (HGF) (62) that when overexpressed enables this compensatory mechanism of pathway activation. Preliminary results of a phase I clinical trial evaluating dual inhibition of EGFR and HGF with erlotinib and rilotumumab (AMG 102), a HGF-binding monoclonal antibody, have recently been reported (63) and a phase II study is on-going.

\section{EGFR AND HSP 90 INHIBITORS}

As a molecular chaperone for proteins involved in MET, HGF, and EML4/ALK fusion, the inhibition of heat shock protein 90 (HSP90) is also being considered as a target for compensatory pathway inhibition and has fueled combination therapies in both EGFR-TKI and ALK inhibitor-resistant disease. In the advanced NSCLC EGFR-TKI resistant setting, the HSP90 small molecule inhibitor AUY922 is being evaluated as monotherapy in a phase II clinical trial vs. pemetrexed or docetaxel in patients with tumors with activating EGFR mutations (www.clinicaltrials.gov: NCT016461250). This agent is also being assessed in a phase II trial in patients with de novo resistant T790M mutations not previously treated with EGFR-TKIs (www.clinicaltrials.gov: NCT01854034) and in patients with EGFR mutations and/or EGFR-TKI resistant disease, as part of a phase II cluster study in Chinese patients evaluating five novel inhibitors of HSP90, PI3K, ALK, MET, and MEK (64). Further, AUY922 is also being assessed in combination with erlotinib in patients who have previously responded to EGFR-TKIs and/or whose tumors harbor activating EGFR mutations (www.clinicaltrials.gov: NCT01259089), with results expected in the near future. The safety and activity of another HSP90 inhibitor, ganetespib (STA-9090), has also been assessed in a heavily pre-treated population with NSCLC in a phase II single arm trial with three cohorts $\left(\mathrm{EGFR}^{+}, \mathrm{KRAS}^{+}\right.$, EGFR/KRAS wild-type) (65). In this study, partial responses were noted in 4/66 patients in the EGFR/KRAS wild-type cohort, all of whom were retrospectively confirmed to have disease that harbored the ALK gene rearrangement (65). Despite interest in this HSP90 inhibitor in combination with chemotherapy (GALAXY1, GALAXY-2) (66, 67), ganetespib's role in inhibiting EGFR is unclear. Given encouraging preclinical data in ALK-driven tumors resistant to crizotinib (68), ganetespib is being investigated in clinical trials in NSCLC patients with ALK-driven tumors, as a monotherapy in heavily treated (crizotinib naïve) patients (www.clinicaltrials.gov: NCT01562015) and in combination with crizotinib in patients with prior exposure to crizotinib (www.clinicaltrials.gov: NCT01579994). 


\section{CONCLUSION}

Over the last decade, our understanding of the EGF receptor and our ability to target it has evolved significantly, from single receptor first-generation inhibitors in unselected populations to biomarker-driven clinical trials of more potent second and thirdgeneration irreversible multi-targeted EGFR-TKIs and humanized monoclonal antibodies. The failure of earlier trials targeting the EGF receptor was in part due to the lack of good predictive biomarkers of efficacy. The future success of targeted strategies addressing resistance will hinge on our ability to identify these biomarkers and selectively enroll patients to clinical trials, a strategy that has been more successfully applied in the approval of ALK inhibitors. Furthermore, in order to be successful in the acquired resistance setting, rebiopsy, and tailored mechanism-driven strategies will be required at the time of progression, with a concurrent reduction in the toxicity of multi-targeted and combination therapies. Importantly, the knowledge gained from investigations of EGFR and ALK inhibition over the last decade can be applied to the testing of novel therapies targeting newly discovered oncogenic drivers in NSCLC (69) in order to optimize study designs and streamline regulatory approval, to the benefit of all patients with NSCLC.

\section{REFERENCES}

1. World Health Organization. Factsheet No 310: The Top Ten Causes of Death (2008). Available from: http://www.who.int/mediacentre/factsheets/ fs310_2008.pdf

2. American Cancer Society. Cancer Facts \& Figures 2009. Atlanta, GA: American Cancer Society, Inc (2009).

3. Schiller JH, Harrington D, Belani CP, Langer C, Sandler A, Krook J, et al. Comparison of four chemotherapy regimens for advanced non-small-cell-lung-cancer. N Engl J Med (2002) 346:92-8. doi:10.1056/NEJMoa011954

4. Lee CK, Brown C, Gralla RJ, Hirsh V, Thongprasert S, Tsai CM, et al. Impact of EGFR inhibitor in non-small cell lung cancer on prognosis-free and overall survival: a meta-analysis. J Natl Cancer Inst (2013) 105(9):595-605. doi:10.1093/jnci/djt072

5. Kris MG, Johnson BE, Berry LD, Kwiatkowski DJ, Iafrate AJ, Wistuba II, et al. Treatment with therapies matched to oncogenic drivers improves survival in patients with lung cancers: results from the lung cancer mutation consortium (LCMC). J Thorac Oncol (2013) 8(2):S3-4. doi:10.1001/jama.2014.3741

6. Krasinskas AM. EGFR signalling in colorectal carcinoma. Patholog Res Int (2011) 2011:932932. doi:10.4061/2011/932932

7. Bethune G, Bethune D, Ridgway N, Xu Z. Epidermal growth factor receptor (EGFR) in lung cancer: an overview and update. J Thorac Oncol (2010) 2:48-51.

8. Hirsch FR, Varella-Garcia M, Bunn PA Jr, Di Maria MV, Veve R, Bremmes RM, et al. Epidermal growth factor receptor in non-small-cell lung carcinomas: correlation between gene copy number and protein expression and impact on prognosis. J Clin Oncol (2003) 21(20):3798-807. doi:10.1200/JCO.2003.11.069

9. Fujino S, Enokibori T, Tezuka N, Asada Y, Inoue S, Kato H, et al. A comparison of epidermal growth factor receptor levels and other prognostic parameters in non-small cell lung cancer. Eur J Cancer (1996) 32A:2070-4. doi:10.1016/S0959-8049(96)00243-2

10. Shepherd FA, Rodrigues Pereira J, Ciuleanu T, Tan EH, Hirsh V, Thongprasert $\mathrm{S}$, et al. Erlotinib in previously treated non-small cell lung cancer. $N$ Engl J Med (2005) 353:123-32. doi:10.1056/NEJMoa050753

11. Thatcher N, Chang A, Parikh P, Rodrigues Pereira J, Ciuleanu T, von Pawel J, et al. Gefitinib plus best supportive care in previously treated patients with refractory advanced non-small cell lung cancer: results from a randomized placebocontrolled, multicentre study (Iressa Survival Evaluation in Lung Cancer). Lancet (2005) 366:1527-37. doi:10.1016/S0140-6736(05)67625-8

12. Fukuoka M, Yano S, Giaccone G, Tamura T, Nakagawa K, Douillard JY, et al. Multi-institutional randomized phase II trial of gefitinib for previously treated patients with advanced non-small-cell lung cancer. J Clin Oncol (2003) 21:2237-46. doi:10.1200/JCO.2003.10.038
13. Kris MG, Natale RB, Herbst RS, Lynch TJ Jr, Prager D, Belani CP, et al. Efficacy of gefitinib, an inhibitor of the epidermal growth factor receptor tyrosine kinase, in symptomatic patients with non-small cell lung cancer: a randomized trial. JAMA (2003) 290:2149-58. doi:10.1001/jama.290.16.2149

14. Giaccone G, Herbst RS, Manegold C, Scagliotti G, Rosell R, Miller V, et al. Gefitinib in combination with gemcitabine and cisplatin in advanced non-small cell lung cancer: a phase III trial - INTACT 1. J Clin Oncol (2004) 22:777-84. doi:10.1200/JCO.2004.08.001

15. Herbst RS, Giaccone G, Schiller JH, Natale RB, Miller V, Manegold C, et al. Gefitinib in combination with paclitaxel and carboplatin in advanced non-small cell lung cancer: phase III trial: INTACT 2. J Clin Oncol (2004) 22:785-94. doi:10.1200/JCO.2004.07.215

16. Herbst RS, Prager D, Hermann F, Fehrenbacher L, Johnson BE, Sandler A, et al. TRIBUTE: a phase III trial of erlotinib hydrochloride (OSI-774) combined with carboplatin and paclitaxel chemotherapy in advanced non-small cell lung cancer. J Clin Oncol (2005) 23:5892-9. doi:10.1200/JCO.2005.02.840

17. Gatzemeier U, Pluzanska A, Szczesna A, Kaukel E, Roubec J, De Rosa F, et al. Phase III study of erlotinib in combination with cisplatin and gemcitabine in advanced non small cell lung cancer: the tarceva lung cancer investigation trial. J Clin Oncol (2007) 25:1545-52. doi:10.1200/JCO.2005.05.1474

18. Lynch TJ, Bell DW, Sordella R, Gurubhagavatula S, Okimoto RA, Brannigan BW, et al. Activating mutations in the epidermal growth factor receptor underlying responsiveness of non-small cell lung cancer to gefitinib. N Engl J Med (2004) 350:2129-39. doi:10.1056/NEJMoa040938

19. Paez JG, Jänne PA, Lee JC, Tracy S, Greulich H, Gabriel S, et al. EGFR mutations in lung cancer: correlation with clinical response to gefitinib therapy. Science (2004) 304:1497-500. doi:10.1126/science.1099314

20. Hirsch F, Varella-Garcia M, Bunn P, Franklin WA, Dziadziuszko R, Thatcher $\mathrm{N}$, et al. Molecular analysis of EGFR gene copy number, EGFR expression and AKT activation in advanced non-small cell lung cancer treated with gefitinib or placebo [ISEL trial]: AACR-NCI-EORTC. International Conference: Molecular Targets and Therapeutics, Philidelphia, PA (2005).

21. Tsao MS, Sakurada A, Cutz JC, Zhu CQ, Kamel-Reid S, Squire J, et al. Erlotinib in lung cancer-molecular and clinical predictors of outcome. N Engl J Med (2005) 353:133-44. doi:10.1056/NEJMoa050736

22. Mok TS, Wu YL, Thongprasert S, Yang CH, Chu DT, Saijo N, et al. Gefitinib or carboplatin-paclitaxel in pulmonary adenocarcinoma. N Engl J Med (2009) 361:947-57. doi:10.1056/NEJMoa0810699

23. Han JY, Park K, Kim SW, Lee DH, Kim HY, Kim HT, et al. First-SIGNAL: firstline single-agent Iressa versus gemcitabine and cisplatin trial in never smokers with adenocarcinoma of the lung. J Clin Oncol (2012) 30(10):1122-8. doi:10.1200/JCO.2011.36.8456

24. Inoue A, Kobayashi K, Maemondo M, Sugawara S, Oizumi S, Isobe H, et al. Updated overall survival results from a randomized phase III trial comparing gefitinib with carboplatin-paclitaxel for chemo-naïve non-small cell lung cancer with sensitive EGFR gene mutations (NEJ002). Ann Oncol (2013) 24(1):54-9. doi:10.1093/annonc/mds214

25. Mitsudomi T, Morita S, Yatabe Y, Negoro S, Okamoto I, Tsurutani J, et al. Gefitinib versus cisplatin plus docetaxel in patients with non-small cell lung cancer harbouring mutations of the epidermal growth factor receptor (WJTOG3405): an open label, randomized phase 3 trial. Lancet Oncol (2010) 11:121-8. doi:10.1016/S1470-2045(09)70364-X

26. Zhou C, Wu YL, Chen G, Feng J, Liu XQ, Wang C, et al. Erlotinib versus chemotherapy as first-line treatment for patients with advanced EGFR-mutation positive non-small cell lung cancer (OPTIMAL, CTONG-0802): a multicentre, open-label, randomised, phase 3 study. Lancet Oncol (2011) 12(8):735-42. doi:10.1016/S1470-2045(11)70184-X

27. Rosell R, Carcereny E, Gervais R, Vergnenegre A, Massuti B, Felip E, et al. Erlotinib versus standard chemotherapy as first-line treatment for European patients with advanced EGFR mutation-positive non-small-cell lung cancer (EURTAC): a multicentre, open-label, randomised phase 3 trial. Lancet Oncol (2012) 13:239-46. doi:10.1016/S1470-2045(11)70393-X

28. Pirker R. EGFR-directed monoclonal antibodies in non-small cell lung cancer. Target Oncol (2013) 8:47-53. doi:10.1007/s11523-012-0244-7

29. Hanna N, Lilenbaum R, Ansari R, Lynch T, Govindan R, Jänne PA, et al. Phase II trial of cetuximab in patients with previously treated non-small cell lung cancer. J Clin Oncol (2006) 24(33):5253-8. doi:10.1200/JCO.2006.08.2263

30. Pirker R, Pereira JR, Szczesna A, von Pawel J, Krzakowski M, Ramlau R, et al. Cetuximab plus chemotherapy in patients advanced non-small-cell lung cancer 
(FLEX): an open-label randomised phase III trial. Lancet (2009) 373:1525-31. doi:10.1016/S0140-6736(09)60569-9

31. Pirker R, Pereira JR, von Pawel J, Krzakowski M, Ramlau R, Park K, et al. EGFR expression as a predictor of survival for first-line chemotherapy plus cetuximab in patients with advanced non-small-cell lung cancer: analysis of data from the phase 3 FLEX study. Lancet Oncol (2011) 13(1):33-42. doi:10.1016/S1470-2045(11)70318-7

32. Lynch TJ, Patel T, Dreisbach L, McCleod M, Heim WJ, Hermann RC, et al. Cetuximab and first-line taxane/carboplatin chemotherapy in advanced non-small-cell lung cancer: results of the randomized multicenter phase III trials BMS099. J Clin Oncol (2010) 28:911-7. doi:10.1200/JCO.2009. 21.9618

33. Thatcher N Linchy TJ. Cetuximab plus platinum-based chemotherapy as 1st line treatment in patients with non-small cell lung cancer (NSCLC): a meta-analysis of randomized phase II/III trials. 13th World Conference on Lung Cancer; San Francisco (2009). abstr. A3.7.

34. Schiller JH, von Pawel J, Schütt P, Ansari RH, Thomas M, Saleh M, et al. Pemetrexed with or without matuzumab as second-line treatment for patients with a stage IIIB/IV non small cell lung cancer. J Thorac Oncol (2010) 5:1977-85. doi:10.1097/JTO.0b013e3181f4a5c9

35. Weiner LH, Belldegrun A, Rowinsky E, Crawford J, Lockbaum P, Huang S, et al. Updated results from a dose and schedule study of panitumumab (ABX-EGF) monotherapy in patients with advanced solid malignancies. J Clin Oncol (2005) 23:abstr.3059.

36. Dancey JE, Chen XE. Strategies for optimizing combinations of molecularly targeted anticancer agents. Nat Rev Drug Discov (2006) 5:649-59. doi:10.1038/ $\operatorname{nrd} 2089$

37. Ramalingam S, Forster J, Naret C, Evans T, Sulecki M, Lu H, et al. Dual inhibition of the epidermal growth factor receptor with cetuximab, an IgG1 monoclonal antibody, and gefitinib, a tyrosine kinase inhibitor, in patients with refractor non-small cell lung cancer (NSCLC): a phase I study. J Thorac Oncol (2008) 3(3):258-64. doi:10.1097/JTO.0b013e3181653d1b

38. Sandler A, Gray R, Perry MC, Brahmer J, Schiller JH, Dowlati A, et al. Paclitaxelcarboplatin alone or with bevacizumab for non small cell lung cancer. $N$ Engl J Med (2006) 355:2542-50. doi:10.1056/NEJMoa061884

39. Herbst RS, Johnson DH, Mininberg E, Carbone DP, Henderson T, Kim ES, et al. Phase I/II trial evaluating the anti-vascular endothelial growth factor monoclonal antibody bevacizumab in combination with the HER-1/epidermal growth factor receptor tyrosine kinase inhibitor erlotinib for patients with recurrent non-small cell lung cancer. J Clin Oncol (2005) 23:2544-55. doi:10.1200/ JCO.2005.02.477

40. Herbst RS, O'Neill VJ, Fehrenbacher L, Belani CP, Bonomi PD, Hart L, et al. Phase II study of efficacy and safety of bevacizumab in combination with chemotherapy or erlotinib compared with chemotherapy alone for treatment of recurrent or refractory non small cell lung cancer. J Clin Oncol (2007) 25:4743-50. doi:10.1200/JCO.2007.12.3026

41. Lee JS, Hirsh V, Park K, Qin S, Blajman CR, Perng RP, et al. Vandetanib versus placebo in patients with advanced non-small cell lung cancer after prior therapy with an epidermal growth factor tyrosine kinase inhibitor: a randomized, double-blind phase III trial (ZEPHYR). J Clin Oncol (2012) 30(1):1114-21. doi:10.1200/JCO.2011.36.1709

42. Yu HA, Arcila ME, Rekhtman N, Sima CS, Zakowski MF, Pao W, et al. Analysis of tumor specimens at the time of acquired resistance to EGFR-TKI therapy in 155 patients with EGFR-mutant lung cancers. Clin Cancer Res (2013) 19:2240-7. doi:10.1158/1078-0432.CCR-12-2246

43. Miller VA, Hirsh V, Cadranel J, Chen YM, Park K, Kim SW, et al. Afatinib versus placebo for patients with advanced, metastatic non small cell lung cancer after failure of erlotinib, gefitinib or both and one or two lines of chemotherapy (LUXLUNG-1): a phase $2 \mathrm{~b} / 3$ randomized trial. Lancet Oncol (2012) 13(5):528-38. doi:10.1016/S1470-2045(12)70087-6

44. Ellis PM, Liu G, Millward M, Perrone F, Shepherd FA, Sun S, et al. NCIC-CTG BR 26: a phase III randomized, double-blind, placebo controlled trial of dacomitinib versus placebo in patients with advanced/metastatic non-small cell lung cancer (NSCLC) who received prior chemotherapy and a EGFR TKI. 50th ASCO Annual Meeting; Chicago, IL (2014). abstr. 8036.

45. Sequist LV, Yan JCH, Yamamoto N, O’Byrne K, Hirsh V, Mok T, et al. Phase III study of afatinib or cisplatin plus pemetrexed in patients with metastatic lung adenocarcinoma with EGFR mutations. J Clin Oncol (2013) 31(37):3327-34. doi:10.1200/JCO.2012.44.2806
46. Wu YL, Zhou C, Hu CP, Feng J, Lu S, Huang Y, et al. Afatinib versus cisplatin plus gemcitabine for first-line treatment of Asian patients with advanced non-small cell lung cancer harbouring EGFR mutations (LUX-lung 6): an open-label, randomized phase 3 trial. Lancet Oncol (2014) 15(2):213-22. doi:10.1016/S1470-2045(13)70604-1

47. Scagliotti G, Novello S, Ramlau R, Favaretto A, Barlesi F, Akerley W, et al. MARQUEE: a randomized, double-blind, placebo-controlled, phase 3 trial of tivantinib (ARQ 197) plus erlotinib versus placebo plus erlonitib in previously treated patients with locally advanced or metastatic, non-squamous, non-small cell lung cancer (NSCLC). The European Cancer Congress 2013; Amsterdam (2013). abstr. 3410.

48. Spigel DR, Edelman MJ, O’Byrne K, Paz-Ares L, Shames DS, Yu W, et al. Onartuzumab plus erlotinib versus erlotinib in previously treated stage IIIb or IV NSCLC: results from the pivotal phase III randomized, multicenter, placebocontrolled METlung (OAM4971g) global trial. ASCO Annual Meeting; Chicago, IL (2014). abstr. 8000.

49. Chong CR, Janne PA. The quest to overcome resistance to EGFR-targeted therapies in cancer. Nat Med (2013) 19(11):1389-99. doi:10.1038/nm.3388

50. Bean J, Brennan C, Shih JY, Riely G, Viale A, Wang L, et al. MET amplification occurs with or without T790M mutations in EGFR mutant lung tumors with acquired resistance to gefitinib or erlotinib. Proc Natl Acad Sci U S A (2007) 104:20932-7. doi:10.1073/pnas.0710370104

51. Spigel DR, Ervin TJ, Ramlau RA, Daniel DB, Goldschmidt JHJr, Blumenschein GRJr, et al. Randomized phase II trial of onartuzumab combination with erlotinib in patients with advanced non-small cell lung cancer. J Clin Oncol (2013) 31(32):4105-14. doi:10.1200/JCO.2012.47.4189

52. Kwak EL, Bang YJ, Camidge DR, Shaw AT, Solomon B, Maki RG, et al. Anaplastic lymphoma kinase inhibition in non-small-cell lung cancer. N Engl J Med (2010) 363(18):1693-703. doi:10.1056/NEJMoa1006448

53. Mok T, Kim DW, Wu YL, Solomon BJ, Nakagawa K, Mekhail T, et al. First-line crizotinib versus pemetrexed-cisplatin or pemetrexed-carboplatin in patients with advanced ALK-positive non-squamous non-small cell lung cancer (NSCLC): results of a phase III study (PROFILE 1014). ASCO Annual Meeting; Chicago, IL (2014). abstr. 8002.

54. Kim DW, Mehra R, Tan DSW, Felip E, Chow LQM, Camidge DR, et al. Ceritinib in advanced anaplastic lymphoma kinase (ALK)-rearranged (ALK+) non-small cell lung cancer (NSCLC): results of the ASCEND-1 trial. ASCO Annual Meeting; Chicago, IL (2014). abstr 8003.

55. Ramalingam SS, Janne PA, Mok T, O’Byrne K, Boyer MJ, Zhang H, Liang JQ, et al. Randomized, double-blinded study of dacomitinib, an irreversible pan-human epidermal growth factor receptor (HER) inhibitor, versus erlotinib for secondline/third-line therapy of locally advanced/metastatic non-small cell lung cancer (ARCHER 1009). ASCO Annual Meeting; Chicago, IL (2014). abstr. 8018.

56. Janne PA, Ramalingam SS, Yang JCH, Ahn MJ, Kim DW, Kim SW, et al. Clinical activity of the mutant-selective EGFR inhibitor AZD 9291 in patients with EGFR inhibitor-resistant non-small cell lung cancer (NSCLC). ASCO Annual Meeting; Chicago, IL (2014). abstr. 8009.

57. Sequist LV, Soria JC, Gadgeel SM, Wakelee HA, Camidge DR, Varga A, et al. First-in-human evaluation of CO-1686, an irreversible, highly selective tyrosine kinase inhibitor of mutations of EGFR (activating and T790M). ASCO Annual Meeting; Chicago, IL (2014). Abstr. 8010.

58. Thatcher N, Hirsch FR, Szczesna A, Ciuleanu TE, Szafranski W, Dediu M, et al. A randomized, multicenter, open-label, phase III study of gemcitabinecisplatin (GC) chemotherapy plus necitumumab (IMC-11F8/LY3012211) versus GC alone in the first-line treatment of patients (pts) with stage IV squamous non-small cell lung cancer (sq-NSCLC). ASCO Annual Meeting 2014; Chicago, IL (2014). abstr. 8008.

59. Janjigian YY, Smit EF, Horn L, Groen HJM, Camidge R, Gettinger S, et al. Activity of afatinib/cetuximab in patients (pts) with EGFR mutant non-small cell lung cancer (NSCLC) and acquired resistance (AR) to EGFR inhibitors. Ann Oncol (2012) 23(Suppl 9):abstr. 12270. doi:10.1093/annonc/mds466

60. Gainor JF, Varghese AM, Ou SH, Kabraji S, Awad MM, Katayama R, et al. ALK rearrangements are mutually exclusive with mutations in EGFR or KRAS: an analysis of 1,683 patients with non-small cell lung cancer. Clin Cancer Res (2013) 19:4273-81. doi:10.1158/1078-0432.CCR-13-0318

61. Gettinger SN, Bazhenova L, Salgia R, Langer CJ, Gold KA, Rosell R, et al. Updated efficacy and safety of the ALK inhibitor AP26113 in patients (pts) with advanced malignancies, including ALK+ non-small cell lung cancer (NSCLC). ASCO Annual Meeting; Chicago, IL (2014). abstr. 8047. 
62. Yano S, Yamada T, Takeuchi S, Tachibana K, Minami Y, Yatabe Y, et al. Hepatocyte growth factor expression in EGFR mutant lung cancer with intrinsic and acquired resistance to tyrosine kinase inhibitors in a Japanese cohort. J Thorac Oncol (2011) 6:2011-7. doi:10.1097/JTO.0b013e31823ab0dd

63. Tran P, Gooding WE, Villaruz LC, Burns TF, Socinski MA, Tarhini AA et al. Phase I study of rilotumumab (AMG 102), an HGF inhibitor, and erlotinib in patients with advanced non-small cell lung cancer (NSCLC). ASCO Annual Meeting; Chicago, IL (2014). abstr. e19065.

64. Zhou Q, Zhang XC, Peng B, Yu X, Akimov M, Weber BL, et al. A phase II cluster study of single agent AUY922, BYL719, INC 280, LDK378 and MEK162 in Chinese patients with advanced non-small cell lung cancer (NSCLC). ASCO Annual Meeting; Chicago, IL (2014). abstr. TPS8122.

65. Socinski MA, Goldman J, El-Hariry I, Koczywas M, Vukovic V, Horn L, et al. A multicenter phase II study of ganestespib monotherapy in patients with genotypically defined advanced non-small cell lung cancer. Clin Cancer Res (2013) 19(11). doi:10.1158/1078-0432.CCR-12-3381

66. Ramalingam SS, Goss GD, Andric ZG, Bondarenko I, Zaric B, Ceric T, et al. A randomized study of ganetespib, a heat shock protein 90 inhibitor, in combination with docetaxel versus docetaxel alone for second-line therapy of lung adenocarcinoma (GALAXY-1). J Clin Oncol (2013) 31(Suppl):abstr:CRA8007.

67. Ramalingam SS, Zaric B, Ceric T, Ciuleanu TE, Spicer JF, Bondarenko I, et al. Galaxy-2: a randomized phase 3 study of ganetespib in combination with docetaxel versus docetaxel along in patients with advanced lung adenocarcinoma. J Clin Oncol (2014) 32(Suppl):TPS8118.
68. Sang J, Acquaviva J, Friedland JC, Smith DL, Sequeira M, Zhang C, et al. Targeted inhibition of the molecular chaperone Hsp90 overcomes ALK inhibitor resistance in non-small cell lung cancer. Cancer Discov (2013) 3(4):1-14. doi:10.1158/2159-8290.CD-12-0440

69. Pao W, Hutchinson K. Chipping away at the lung cancer genome. Nat Med (2012) 18(2):349-51. doi:10.1038/nm.2697

Conflict of Interest Statement: The authors declare that the research was conducted in the absence of any commercial or financial relationships that could be construed as a potential conflict of interest.

Received: 06 June 2014; accepted: 11 August 2014; published online: 27 August 2014. Citation: Spaans JN and Goss GD (2014) Trials to overcome drug resistance to EGFR and ALK targeted therapies - past, present, and future. Front. Oncol. 4:233. doi: 10.3389/fonc.2014.00233

This article was submitted to Thoracic Oncology, a section of the journal Frontiers in Oncology.

Copyright $(2014$ Spaans and Goss. This is an open-access article distributed under the terms of the Creative Commons Attribution License (CC BY). The use, distribution or reproduction in other forums is permitted, provided the original author(s) or licensor are credited and that the original publication in this journal is cited, in accordance with accepted academic practice. No use, distribution or reproduction is permitted which does not comply with these terms. 